\title{
EXTERNAL TRADE PERFORMANCE AND EXPORTERS' MARKET ORIENTATION. STUDY CASE OF ROMANIA
}

\author{
Elena $B \breve{A N I C \breve{A}^{1}}$ \\ Valentina VASILE ${ }^{2}$
}

\begin{abstract}
Romanian's external trade is dominated by the activity of foreign capital. The main orientations on national market of these firms relate to the mother-company's strategy. In the case of Romanian capital, the evolution is mainly defined by asymmetric sector specialization with low natural resources processing and de-balanced geographical specialization. The paper analyses the companies' orientation on external markets, considering the efficiency of external trade through qualitative parameters: high-tech products, comparative advantages by industries and equilibrium in geographical market orientation. Reducing the prevalence of low-tech and primary products at the level of Romanian exporting companies should be considered as a priority for change for national policies in terms of external trade with goods.
\end{abstract}

Keywords: external trade, foreign capital, specialization, efficiency, Romanian capital

JEL Codes: D22, F14

\section{Introduction}

The process of globalization and the creation of regional markets, such as the single European market, play an important role in the dynamics of integrated national economies and increase the interdependence among them, generating both positive and negative externalities. The foreign capital is very important for an emerging economy in terms of productivity gains, competitiveness on international markets under strong competitive conditions, creation of new jobs (especially highly qualified), implementation of new technologies and transfer of knowledge in the host country of FDI, promotion of modern management systems, etc.

The analysis of foreign trade activity, especially export of goods, as a factor of economic growth, from the point of view of the companies' type of capital, highlights the aspects related to competitiveness and performance. At the same time, it allows identification of those economic sectors where commercial policy can support Romanian companies to develop efficient businesses.

High-tech goods are produced and exported not only by large companies; technological progress has also created an inversely proportionate relationship between the size of the enterprise and the technological level, i.e. ITC companies. Nowadays, however, large companies dominate the market due to their competitive advantage through RDI departments developed within the company. Comparative analysis of labor productivity reveals the greater contribution of exports of goods to the financial and economic results of foreign companies than Romanian ones. The reduced competitiveness of Romanian companies diminishes the potential for entrance on international market.

The dependence of national exports on foreign companies does not produce positive effects in the Romanian economy on the medium and longer term, but only on the short term. Ensuring the protection of national interests and an efficient development of the industry requires the existence of an adequate/sound strategy and an effective policy for its implementation. The development

\footnotetext{
${ }^{1}$ National Institute of Statistics, Romania, elenabanica77@gmail.com

${ }^{2}$ Institute of National Economy-Romanian Academy, valentinavasile2009@gmail.com

DOI: 10.29302/oeconomica.2020.22.1.5
} 
strategy should consider the geographical location of industrial areas (resource efficiency and cost reduction), environmental conditions (the need to protect it), the specificity of the regional labor force (education level, work traditions and its professional development opportunities). Although the number of Romanian companies is growing, their contribution to national export is decreasing. Their small size, the high degree of capital fragmentation, the lack of a national strategic orientation for export activity and no supportive policy measures for promoting domestic products which could compete with similar imports by comparative advantages or lower costs, lead to reduced performances of the Romanian entrepreneurship initiatives.

This paper aims to analyze the behavior of exporting companies classified by type of capital and highlighting the main products and external markets of the companies. The technological aspect is considered, respectively the technology incorporated in the goods produced at national level and exported abroad.

\section{State of the art}

Export is one of the factors of sustainable economic growth (Cerchez, 2007). By contributing to gross domestic product, export can ensure a long-term development of the entire economy. By stimulating the investment activity, companies can produce positive effects in the economy through exports. New jobs are generated, salary increases so as national and international consumption (Vasile \& Banica, 2016).

The internal deficit of financial resources to support economic growth and exports is overcome by the economic activity of foreign capital in Romania. Foreign companies are very important for an emerging economy in terms of productivity, competitiveness, job creation, introduction of new technologies and knowledge, promotion of modern organizational and management systems (Zaman \& Vasile, 2006). Only firms obtaining high level of productivity can grow and access the export market of the most developed countries, and these firms have a higher rate of surviving on these markets (Fernandes, et al., 2016). The decision on the participation in the international market can be explained by the main objective of the companies - to increase the specific market segment and to maximize the profits.

Globalization is a reality generated by the technological and economic developments, which cannot be treated as strategy that can be implemented or not (Liedtke, 2000), (Ghibutiu, 2006). All the countries must keep up with these changes caused by the evolution of the market in order to ensure development and well-being of citizens. Foreign companies record higher levels of labor productivity compared to domestic firms, as well as wage and employment levels (Bănică \& Vasile, 2018) . In addition, foreign companies employ especially highly qualified employees compared to national companies that are not able to apply this strategy; the result is an increased disparity between the two types of companies (Peluffo, 2015).

In the Country Report for Romania in 2018, the European Commission has shown that the business environment has been damaged in recent years (EC, 2018). Some other international reports also revealed a reduction in Romania's attractiveness for foreign investors. Romania lost nine ranks in the World Bank Report Doing Business (World Bank Group, 2018), reaching 45th in terms of facilitating business development while in the Global Competitiveness Report Romania's rank is 68 (from 62 in the previous year) (WEF, 2017). Performance remains an issue in terms of governance, qualification, infrastructure, health and education, with most companies expecting a reduction in investment activity rather than expanding, it in the near future in Romania (European Investment Bank, 2018).

By integrating technology into business, many of the productive activities can be performed automatically, but in some cases at higher costs; so, for companies, it is more efficient to relocate abroad these production stages (Blinder, 2009). As a result, some of the low-skill activities are geared towards developing countries due to their loss of efficiency in developed countries. On the other hand, the foreign companies with FDI positively influences the performance of national firms 
(Aitken \& Harrison, 1999), (Zaman \& Vasile, 2006), (Vasile, 2007), (Vasile \& Zaman, 2012). This situation has several reasons:

a) labor productivity at the level of foreign companies is relatively higher than the one recorded on Romanian companies (Görg \& Strobl, 2001), (Kokko, et al., 2001), (Bănică \& Vasile, 2017),

b) performance management systems, marketing and know-how,

c) traditional business contracts, relationships developed with both suppliers and customers on foreign markets,

d) better capacity to invest in RDI at company level - mostly in main (mother) companies and to cheaper technological transfer to satellite (relocated) branches,

e) advantageous financial loans.

The level of export is directly linked with the level of labor productivity, a higher productivity generating greater competitiveness of goods on foreign markets and higher company level profitability.

Romanian firms can benefit from the relations developed with foreign companies by indirect technology transfer and/or complementarity in production chain (subcontracting). But multinational companies will not directly transfer their own source of comparative advantage. In the literature, four ways by which the host country can achieve higher levels of labor productivity are identified: imitation, skills acquisition, competition and exports (Görg \& Greenaway, 2003).

\section{Description of work}

The research is based on the external trade with goods statistical information for the period 2008-2016. Data used for the analyses was extracted from external trade in goods statistical database held by NIS, on micro level. The grouping method was applied to differentiate the research population, according to the selection variables: the type of capital ownership and technological intensity of the manufacturing industry.

By capital ownership, companies were classified into three categories:

- Romanian capital - companies with entirely Romanian capital, which refer to companies with Romanian state and / or private capital,

- Mixed capital - companies with mixed capital, which refer to companies with Romanian state and / or private capital and foreign capital as well as companies with Romanian private capital and foreign capital,

- Foreign capital - companies with entirely foreign capital, respectively firms entirely owned by foreign entities.

The aggregation of the manufacturing industry according to technological intensity is based on products belonging to the specific activity (CPA 2015). The categories compiled are high-tech goods, medium high-tech goods, medium low-tech goods and low-tech goods.

According to the last two-decade statistical records, Romanian exports are dominated by foreign-owned firms. In 2016 for example, they performed over $85 \%$ of total exports and over $77 \%$ of total imports while their number (companies with entirely foreign capital) is less than $20 \%$ of the total number of foreign trade companies (Bănică \& Vasile, 2018).

Romanian capital firms have a decreasing presence on foreign markets in 2016 against 2008. The contribution of domestic companies to the international value chain of the product is limited and depends on the strategy of multinational companies, mainly because of the complementarity, creating a competitive environment with a strong impact on small firms. 


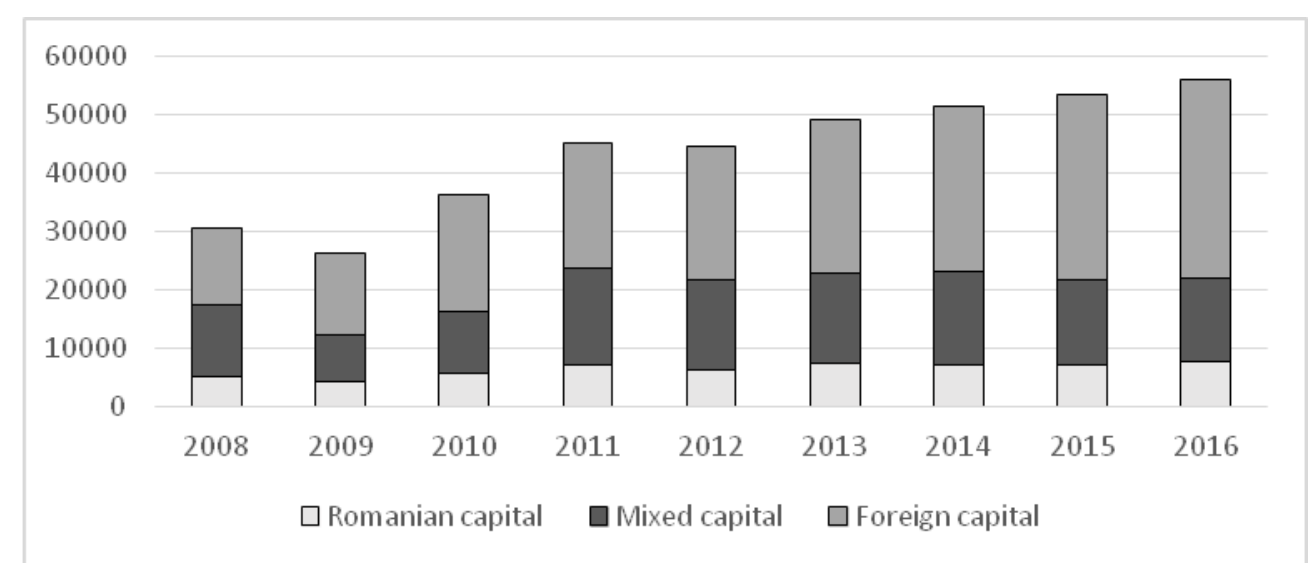

Figure 1. Export of goods by type of capital of the exporting companies (EUR million, current prices)

Data source: Authors' calculations based on NIS data

Romania's export as an economic growth factor has proved to be a circumstantial activity in the period 2008-2016, regardless of the companies' type of capital. Although foreign firms have achieved higher levels of labor productivity than Romanian firms (Bănică \& Vasile, 2018), their activity has been influenced by global events in the analyzed period. We refer firstly and foremost to Romania's EU accession in 2007, when foreign trade has achieved the most important liberalization degree through the complete elimination of customs duties in trade relations with EU Member States, as well as the economic and financial crisis of 2008-2009.

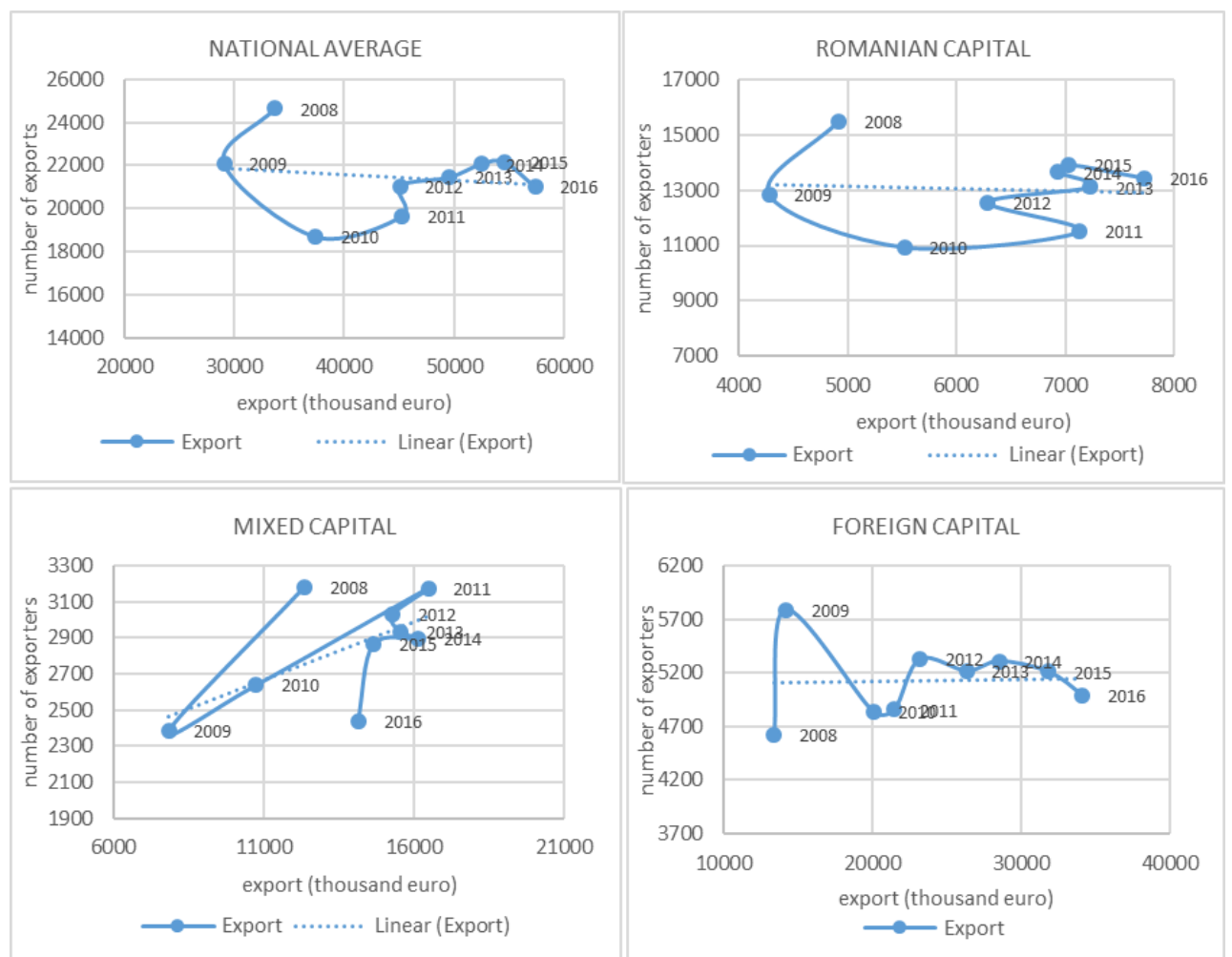

Figure 2. Export of goods and number of exporting companies in Romania, by type of capital

Data source: Authors' calculations based on NIS data

During the economic crisis, the Romanian and mixed capital companies decreased in both number and volume of exports; foreign capital companies recorded a stagnation of exports and an 
increase in the number of firms. The recovered after crisis was earlier than in other companies' case, in 2010 already recorded significant increases in exports. It proves that foreign firms contributed to the recovery of Romania's activity mainly by intensifying their exports.

In order to analyze the exporting companies volatility on market, the company's entry and, respectively exit rate on the Romanian market, by type of capital ownership were calculated (Fernandez, et al., 2016):

Company entry rate $($ year $t)=$ number of new firms in year $t /$ total number of exporters in year $\mathrm{t}$ Where:

Company exit rate $($ year $\mathrm{t})=$ number of firms out in year $\mathrm{t} /$ total number of exporters in year $\mathrm{t}$

New firm = company that did not export goods in year $\mathrm{t}-1$, but exported in year $\mathrm{t}$

Exiter company = company that exported in year $\mathrm{t}-1$ but does not export in year $\mathrm{t}$

Table 1.

Firm dynamics by type of capital, in Romania, 2009-2016

\begin{tabular}{|c|c|c|c|c|c|c|c|c|}
\hline & \multicolumn{2}{|c|}{ National average } & \multicolumn{2}{c|}{ Romanian capital } & \multicolumn{2}{c|}{ Mixed capital } & \multicolumn{2}{c|}{ Foreign capital } \\
\cline { 2 - 10 } & $\begin{array}{c}\text { Firm } \\
\text { entry } \\
\text { rate }\end{array}$ & $\begin{array}{c}\text { Firm } \\
\text { exit } \\
\text { rate }\end{array}$ & $\begin{array}{c}\text { Firm } \\
\text { entry } \\
\text { rate }\end{array}$ & $\begin{array}{c}\text { Firm } \\
\text { exit } \\
\text { rate }\end{array}$ & $\begin{array}{c}\text { Firm } \\
\text { entry } \\
\text { rate }\end{array}$ & $\begin{array}{c}\text { Firm } \\
\text { exit } \\
\text { rate }\end{array}$ & $\begin{array}{c}\text { Firm } \\
\text { entry } \\
\text { rate }\end{array}$ & $\begin{array}{c}\text { Firm } \\
\text { exit } \\
\text { rate }\end{array}$ \\
\hline 2009 & 0.28 & 0.33 & 0.28 & 0.34 & 0.16 & 0.33 & 0.20 & 0.18 \\
\hline 2010 & 0.30 & 0.29 & 0.32 & 0.27 & 0.19 & 0.16 & 0.21 & 0.24 \\
\hline 2011 & 0.31 & 0.25 & 0.33 & 0.26 & 0.16 & 0.16 & 0.22 & 0.20 \\
\hline 2012 & 0.30 & 0.26 & 0.32 & 0.27 & 0.15 & 0.18 & 0.18 & 0.20 \\
\hline 2013 & 0.30 & 0.29 & 0.28 & 0.30 & 0.15 & 0.18 & 0.18 & 0.21 \\
\hline 2014 & 0.42 & 0.38 & 0.41 & 0.38 & 0.22 & 0.25 & 0.27 & 0.28 \\
\hline 2015 & 0.45 & 0.51 & 0.48 & 0.45 & 0.26 & 0.28 & 0.32 & 0.35 \\
\hline 2016 & 0.39 & 0.21 & 0.40 & 0.21 & 0.30 & 0.19 & 0.29 & 0.14 \\
\hline
\end{tabular}

Data source: Authors' calculations based on NIS data

In the analyzed period was registered a higher dynamic at the level of Romanian companies than in the other two cases (mixed and foreign capital firms). Moreover, data revealed a reduced dynamic of the exporting companies at national level, which shows a relative stability of the firms on the market. It should be mentioned that the export was the only macroeconomic indicator with atypical evolution short time after the crisis. It recorded a positive evolution starting with 2010 based to the activity of foreign firms that have focused mainly on exports of high technology goods, in order to compensate the reductions recorded in the countries of origin of the capital, because of the crisis.

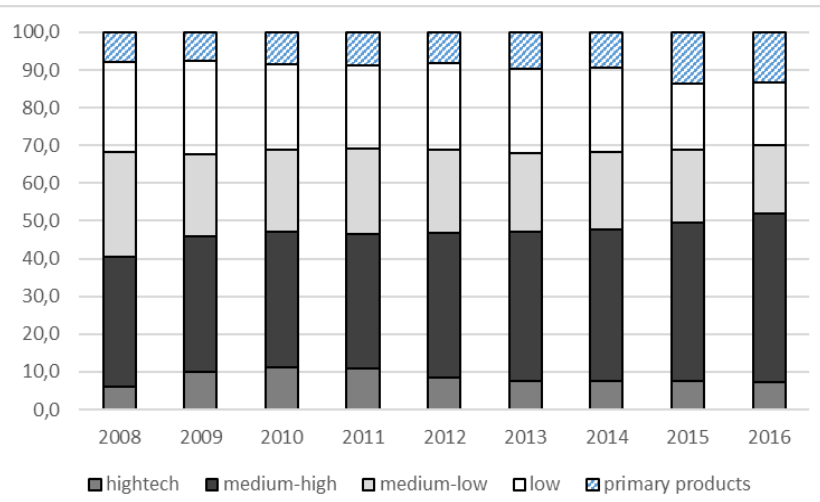

Figure 3. Romania's export of goods, by technology (\% in total export)

Data source: Authors' calculations based on NIS data 


\section{Exports of high-tech products}

The share of high-tech goods in national exports is particularly low, being mainly produced and exported by foreign-owned firms. Foreign companies are attracted by the opportunities identified on the Romanian market in terms of reduced labor costs and the availability of primary resources. Goods are exported with a low processing rate, while the greatest share of value added is recorded in the countries of origin of capital, by the technologies applied with minimum human effort and financial costs. Moreover, the share of primary products in national exports is increasing during the analyzed period.

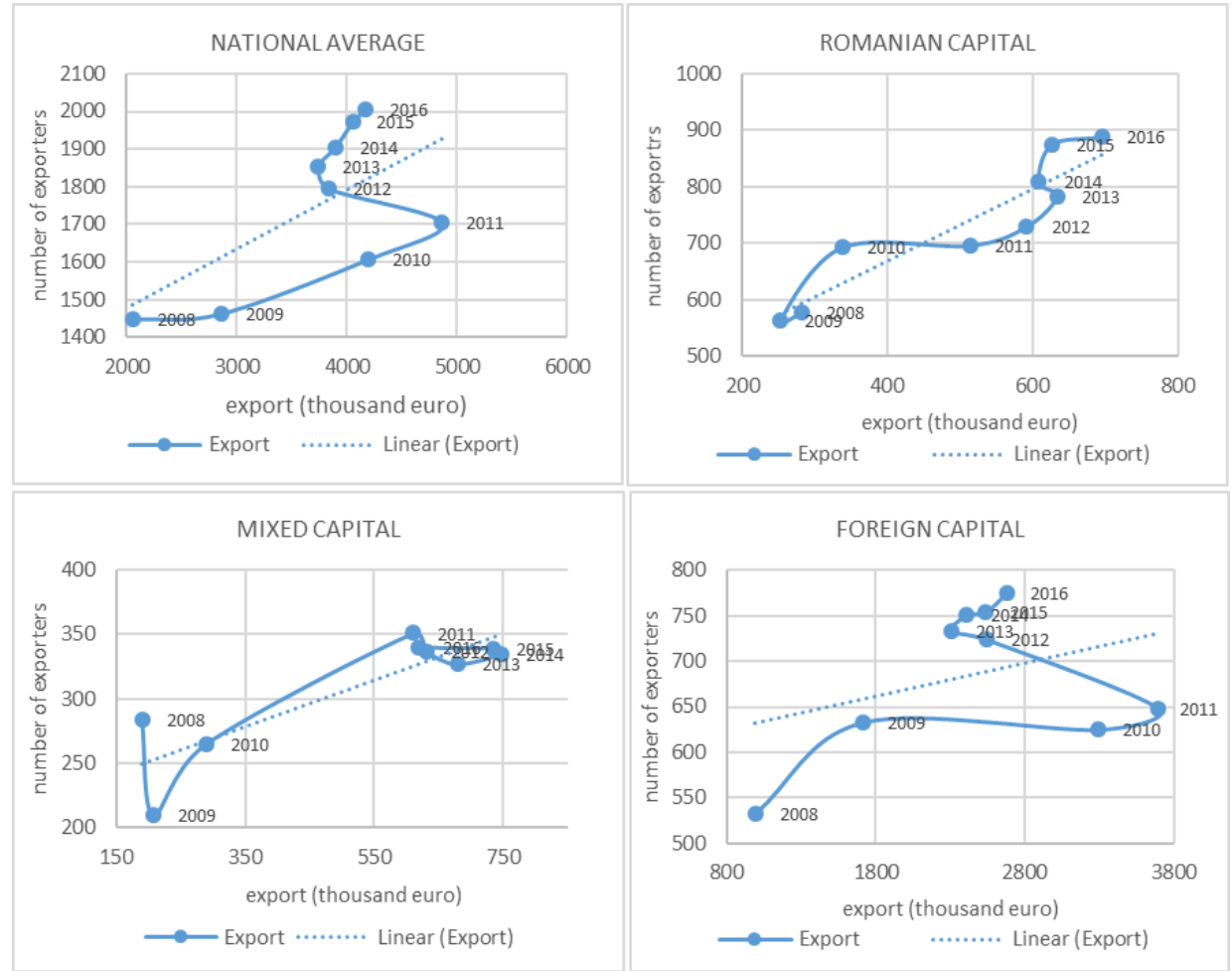

Figure 4. Export and number of exporting companies of high-tech goods, by type of capital

Data source: Authors' calculations based on NIS data

A relatively constant and positive evolution from the point of view of the volume of exports and of the number of companies is registered at the level of the Romanian companies. However, their limited production capacity as well as the lower technological level severely limits their commercial expansion potential. The volume of high-tech goods exported by the Romanian capital has the lowest value among the types of companies analyzed (16\% of high-tech exports and only $1 \%$ of national exports in 2016).

The evolution of the foreign capital presented in Figure 4 shows that its activity is strongly conditioned by the policies pursued at the level of the multinational companies. The year 2011 marks a cut-off in high-tech export, based on global economic recovery after the economic crisis and restarting of commercial activity on a cost-effective manner and maximizing profits. Thus, after the significant growth of exports during 2008-2010, in 2011 the volume of exports declined.

In the same year 2011, the mixed capital companies recorded a stagnation of exports, in both volume of exports and the number of companies.

The detailed statistical data at the level of exporting companies of high-tech goods, underlines a concentration of the Romanian capital on two main markets (about $40 \%$ of the number of companies in this segment in 2016): a) electrical machines and apparatus, b) optical instruments, 
measuring and control instruments. However, these two markets are not the most important ones in terms of export value; the value added in Romania for these goods is reduced due to the low intensity and old technology used in manufacturing industry $(6 \%$ and, respectively, $1 \%$ of high-tech exports). The largest share of domestic capital in the value of exports of high-tech goods (7\% in 2016) is held by the pharmaceutical sector, where Romanian companies account for $6 \%$ of the total number of exporting companies of high-tech goods.

Table 2.

Romania's exports of high-tech goods by type of capital (\% of total exports of hightech goods) and the number of companies

\begin{tabular}{|c|c|c|c|c|c|c|c|c|c|c|}
\hline & \multicolumn{2}{|c|}{2008} & \multicolumn{2}{|c|}{2010} & \multicolumn{2}{|c|}{2012} & \multicolumn{2}{|c|}{2014} & \multicolumn{2}{|c|}{2016} \\
\hline & $\begin{array}{l}\% \text { in } \\
\text { value }\end{array}$ & $\begin{array}{l}\text { No. of } \\
\text { comp. }\end{array}$ & $\begin{array}{l}\% \text { in } \\
\text { value }\end{array}$ & $\begin{array}{l}\text { No. of } \\
\text { comp. }\end{array}$ & $\begin{array}{l}\% \text { in } \\
\text { value }\end{array}$ & $\begin{array}{l}\text { No. of } \\
\text { comp. }\end{array}$ & $\begin{array}{l}\% \text { in } \\
\text { value }\end{array}$ & $\begin{array}{l}\text { No. of } \\
\text { comp. }\end{array}$ & $\begin{array}{l}\% \text { in } \\
\text { value }\end{array}$ & $\begin{array}{l}\text { No. of } \\
\text { comp. }\end{array}$ \\
\hline $\begin{array}{l}\text { Export of high-tech } \\
\text { goods, of which: }\end{array}$ & 100.0 & 1449 & 100.0 & 1608 & 100.0 & 1795 & 100.0 & 1906 & 100.0 & 2005 \\
\hline $\begin{array}{l}\text { Romanian capital, } \\
\text { of which: }\end{array}$ & 13.7 & 577 & 8.0 & 693 & 15.4 & 729 & 15.6 & 809 & 16.7 & 888 \\
\hline $\begin{array}{r}\text { Computers, } \\
\text { electronic products }\end{array}$ & 6.1 & 258 & 2.2 & 304 & 4.4 & 307 & 5.0 & 321 & 6.3 & 399 \\
\hline Optical instruments & 1.2 & 202 & 0.6 & 275 & 0.6 & 311 & 0.7 & 352 & 1.2 & 393 \\
\hline $\begin{array}{r}\text { Mechanical } \\
\text { apparatus and } \\
\text { devices }\end{array}$ & 1.7 & 170 & 0.8 & 155 & 0.8 & 184 & 0.7 & 183 & 0.9 & 222 \\
\hline $\begin{array}{r}\text { Pharmaceutical } \\
\text { products }\end{array}$ & 1.0 & 37 & 3.9 & 76 & 8.0 & 87 & 7.2 & 133 & 6.7 & 118 \\
\hline $\begin{array}{l}\text { Mixed capital, of } \\
\text { which: }\end{array}$ & 9.3 & 284 & 6.9 & 265 & 16.4 & 337 & 19.2 & 335 & 14.8 & 340 \\
\hline Optical instruments & 1.5 & 138 & 1.4 & 115 & 1.5 & 155 & 2.1 & 155 & 2.7 & 172 \\
\hline $\begin{array}{r}\text { Computers, } \\
\text { electronic products }\end{array}$ & 4.3 & 135 & 1.2 & 119 & 5.2 & 160 & 6.9 & 148 & 3.5 & 162 \\
\hline $\begin{array}{r}\text { Mechanical } \\
\text { apparatus and } \\
\text { devices }\end{array}$ & 0.8 & 92 & 0.2 & 82 & 1.7 & 95 & 1.0 & 99 & 0.7 & 92 \\
\hline $\begin{array}{r}\text { Pharmaceutical } \\
\text { products }\end{array}$ & 1.4 & 18 & 3.7 & 22 & 6.3 & 33 & 6.2 & 44 & 5.5 & 40 \\
\hline $\begin{array}{l}\text { Foreign capital, of } \\
\text { which: }\end{array}$ & 48.3 & 532 & 78.6 & 625 & 66.3 & 724 & 61.8 & 751 & 64.3 & 775 \\
\hline Optical instruments & 3.0 & 244 & 16.8 & 293 & 18.2 & 350 & 19.5 & 387 & 20.3 & 415 \\
\hline $\begin{array}{r}\text { Computers, } \\
\text { electronic products }\end{array}$ & 3.0 & 246 & 17.0 & 325 & 20.2 & 372 & 20.7 & 363 & 19.0 & 381 \\
\hline $\begin{array}{r}\text { Mechanical } \\
\text { apparatus and } \\
\text { devices }\end{array}$ & 3.0 & 173 & 11.9 & 203 & 12.6 & 205 & 11.4 & 223 & 11.7 & 205 \\
\hline $\begin{array}{r}\text { Pharmaceutical } \\
\text { products }\end{array}$ & 3.0 & 25 & 1.7 & 38 & 2.4 & 61 & 3.4 & 56 & 2.9 & 57 \\
\hline
\end{tabular}

Data source: Authors' calculations based on NIS data

Foreign-owned companies are concentrated on the same two economic sectors as Romanian ones are, namely electrical machinery and optical instruments (53\% of the total number of exporting companies of high-tech goods with a cumulative export value of $39 \%$ in 2016). Thus, a particularly important aspect regarding the performance of companies by type of capital is highlighted: with the same number of companies, the export performed by foreign companies is higher than the value recorded by the Romanian companies. 
Higher productivity reached by the implementation of new technologies (or at least the next technological level), integration on the international productive value chain and the comparative advantage obtained in Romania by lower labor costs, lead to a better economic profitability. Competition in this area is strong, and a national investments and incentive support policies for firms geared to technologically intensive sectors could lead to improved domestic capital performance.

From the point of view of geographic distribution, the export of high-tech goods is concentrated mainly on the European markets and on the countries of origin of FDI companies.

Table 3.

Geographic distribution of the number of firms with high-tech exports by type of capital (\% of total exports of high-tech goods)

\begin{tabular}{|c|c|c|c|c|c|c|c|c|c|c|}
\hline & \multicolumn{2}{|c|}{2008} & \multicolumn{2}{|c|}{2010} & \multicolumn{2}{|c|}{2012} & \multicolumn{2}{|c|}{2014} & \multicolumn{2}{|c|}{2016} \\
\hline & $\begin{array}{c}\% \text { in } \\
\text { value }\end{array}$ & $\begin{array}{l}\text { No. of } \\
\text { comp. }\end{array}$ & $\begin{array}{c}\% \text { in } \\
\text { value }\end{array}$ & $\begin{array}{l}\text { No. of } \\
\text { comp. }\end{array}$ & $\begin{array}{c}\% \text { in } \\
\text { value }\end{array}$ & $\begin{array}{l}\text { No. of } \\
\text { comp. }\end{array}$ & $\begin{array}{c}\% \text { in } \\
\text { value }\end{array}$ & $\begin{array}{l}\text { No. of } \\
\text { comp. }\end{array}$ & $\begin{array}{c}\% \text { in } \\
\text { value }\end{array}$ & $\begin{array}{l}\text { No. of } \\
\text { comp. }\end{array}$ \\
\hline $\begin{array}{l}\text { Export of high-tech } \\
\text { goods, of which: }\end{array}$ & 100.0 & 1449 & 100.0 & 1608 & 100.0 & 1795 & 100.0 & 1906 & 100.0 & 2005 \\
\hline $\begin{array}{l}\text { Romanian capital, } \\
\text { of which: }\end{array}$ & 13.7 & 577 & 8.0 & 693 & 15.4 & 729 & 15.6 & 809 & 16.7 & 888 \\
\hline Intra-EU, of which: & 8.8 & n.a. & 6.6 & n.a. & 12.5 & n.a. & 12.6 & n.a. & 13.6 & n.a. \\
\hline Germany & 0.4 & 55 & 2.3 & 96 & 4.7 & 122 & 4.7 & 141 & 3.4 & 142 \\
\hline United Kingdom & 0.9 & 26 & 0.7 & 53 & 1.8 & 80 & 1.7 & 103 & 1.6 & 118 \\
\hline Extra-EU, of which: & 4.9 & n.a. & 1.4 & n.a. & 2.9 & n.a. & 3.0 & n.a. & 3.1 & n.a. \\
\hline Rep. Moldova & 0.2 & 131 & 0.2 & 157 & 0.2 & 192 & 0.4 & 229 & 0.3 & 265 \\
\hline USA & 0.4 & 89 & 0.2 & 90 & 0.2 & 83 & 0.3 & 86 & 0.3 & 95 \\
\hline $\begin{array}{l}\text { Mixed capital, of } \\
\text { which: }\end{array}$ & 9.3 & 284 & 6.9 & 265 & 16.4 & 337 & 19.2 & 335 & 14.8 & 340 \\
\hline Intra-EU, of which: & 5.7 & n.a. & 5.6 & n.a. & 13.4 & n.a. & 14.9 & n.a. & 10.2 & n.a. \\
\hline Germany & 1.2 & 37 & 2.5 & 43 & 6.9 & 70 & 7.4 & 67 & 3.6 & 60 \\
\hline Hungary & 1.1 & 26 & 0.1 & 34 & 0.6 & 50 & 0.6 & 44 & 0.6 & 56 \\
\hline Extra-EU, of which: & 3.6 & n.a. & 1.3 & n.a. & 3.0 & n.a. & 4.2 & n.a. & 4.6 & n.a. \\
\hline Rep. Moldova & 0.3 & 67 & 0.1 & 56 & 0.1 & 68 & 0.2 & 85 & 0.1 & 79 \\
\hline USA & 0.1 & 38 & 0.1 & 38 & 1.0 & 47 & 0.5 & 42 & 0.3 & 51 \\
\hline $\begin{array}{l}\text { Foreign capital, of } \\
\text { which: }\end{array}$ & 48.3 & 532 & 78.6 & 625 & 66.3 & 724 & 61.8 & 751 & 64.3 & 775 \\
\hline Intra-EU, of which: & 37.6 & n.a. & 58.5 & n.a. & 55.6 & n.a. & 51.0 & n.a. & 53.5 & n.a. \\
\hline Germany & 6.9 & 91 & 9.4 & 109 & 8.6 & 127 & 11.7 & 152 & 19.4 & 160 \\
\hline Italy & 4.1 & 105 & 10.1 & 109 & 9.7 & 127 & 8.1 & 126 & 8.6 & 143 \\
\hline Extra-EU, of which: & 10.7 & n.a. & 20.1 & n.a. & 10.7 & n.a. & 10.9 & n.a. & 10.7 & n.a. \\
\hline Rep. Moldova & 0.1 & 106 & 0.1 & 104 & 0.3 & 117 & 0.3 & 118 & 0.3 & 136 \\
\hline USA & 1.7 & 71 & 0.7 & 84 & 1.3 & 94 & 2.4 & 111 & 2.7 & 105 \\
\hline
\end{tabular}

Data source: Authors' calculations based on NIS data

In the present, the foreign trade is de-balanced by geographical distribution and producer's ownership. The identification of new markets for export in the extra-EU countries together with increasing of the quality of Romanian products and an improved promotion of goods, can lead to a reduction of the dependence of Romania's exports on foreign capital and the EU markets as well as to an equilibrum of trade balance.

On national level, in 2016 Romania recorded commercial surplus mainly in relation with United Kingdom, France and, from extra-EU countries, with Egypt, United Arab Emirates and Maroc (NSI Romania, 2017). These are partners where important markets in terms of value can be developed for romanian products. 


\section{Exports of medium-high technological products}

The highest share of Romania's exports is medium-high technology goods (35\% in 2008 and $45 \%$ in 2016). The analysis of export by type of capital is relevant for highlighting the emerging economic sectors , especially from the point of view of Romanian companies.

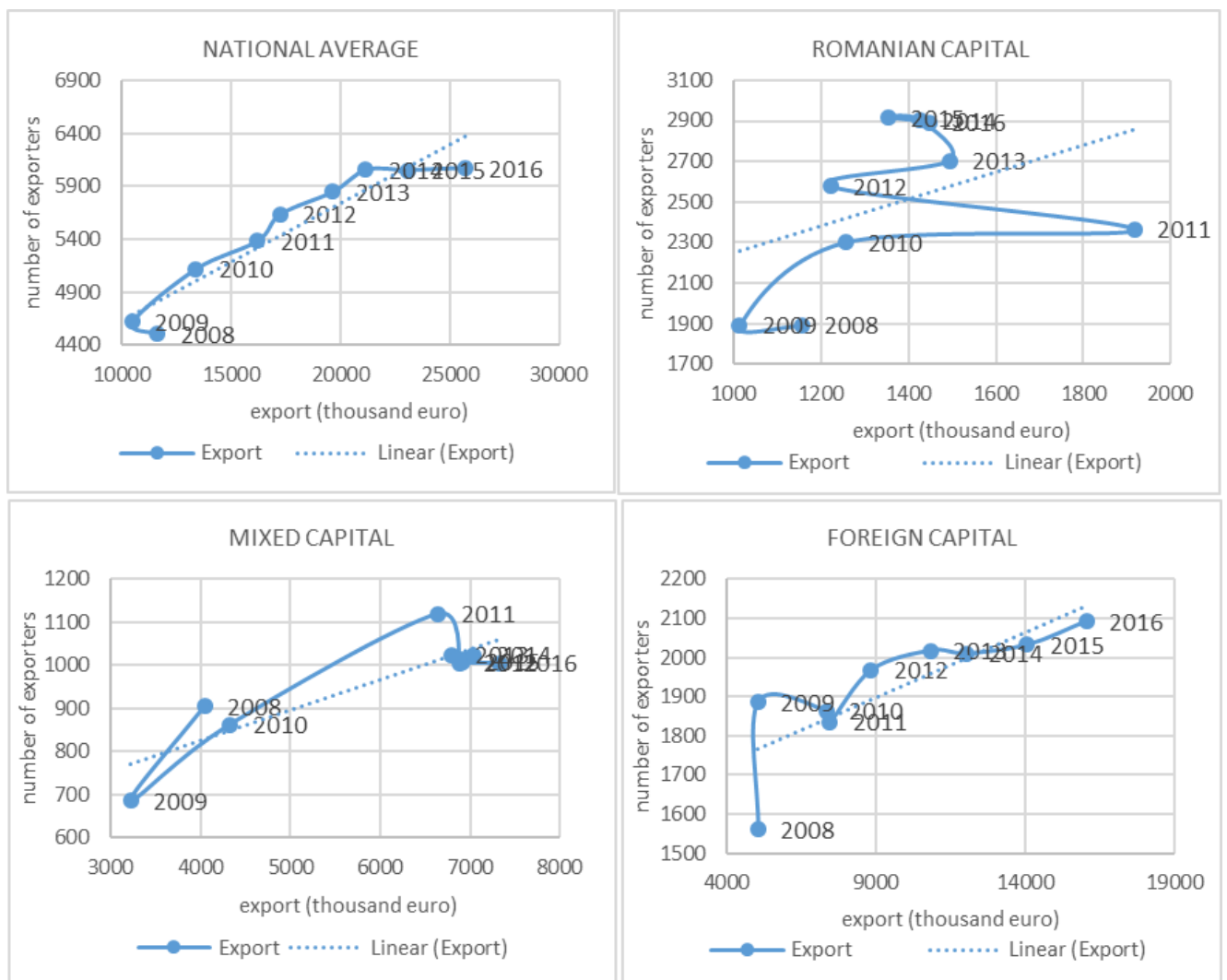

Figure 5. Export and number of exporting companies of medium-high technology goods, by type of capital

Data source: Authors' calculations based on NIS data

Before 2011, the Romanian companies accessed the foreign markets by medium-high technology goods using the advantage offered by the price; ones the developed economies recovered after crises, the quality standards have increased, and the behavior of the big international firms has become defensive and cautious. Therefore, the demand for Romanian products has fallen in favor of better-known products, adapted to foreign consumers from the point of view of presentation and brand tradition. The digitalization process (e.g. integrated planning approaches in production and goods distribution) increased even more the competition, being directly linked with the ability of each firm to adapt to technological changes. Another factor influencing the international trade is the protectionist tendency of developed economies, rising in recent years worldwide (outside the EU). 
Table 4.

Exports of medium-high technology goods of Romania by type of capital (\% of the total export of medium-high technology goods) and the number of companies in this category

\begin{tabular}{|c|c|c|c|c|c|c|c|c|c|c|}
\hline & \multicolumn{2}{|c|}{2008} & \multicolumn{2}{|c|}{2010} & \multicolumn{2}{|c|}{2012} & \multicolumn{2}{|c|}{2014} & \multicolumn{2}{|c|}{2016} \\
\hline & $\begin{array}{l}\% \text { in } \\
\text { value }\end{array}$ & $\begin{array}{l}\text { No. of } \\
\text { comp. }\end{array}$ & $\begin{array}{l}\% \text { in } \\
\text { value }\end{array}$ & $\begin{array}{l}\text { No. of } \\
\text { comp. }\end{array}$ & $\begin{array}{l}\% \text { in } \\
\text { value }\end{array}$ & $\begin{array}{l}\text { No. of } \\
\text { comp. }\end{array}$ & $\begin{array}{l}\% \text { in } \\
\text { value }\end{array}$ & $\begin{array}{l}\text { No. of } \\
\text { comp. }\end{array}$ & $\begin{array}{l}\% \text { in } \\
\text { value }\end{array}$ & $\begin{array}{l}\text { No. of } \\
\text { comp. }\end{array}$ \\
\hline $\begin{array}{l}\text { Export of } \\
\text { medium-high } \\
\text { technology goods, } \\
\text { of which: }\end{array}$ & 100.0 & 4504 & 100.0 & 5120 & 100.0 & 5636 & 100.0 & 6054 & 100.0 & 6072 \\
\hline $\begin{array}{l}\text { Romanian capital, } \\
\text { of which: }\end{array}$ & 9.9 & 1891 & 9.4 & 2301 & 7.1 & 2576 & 6.7 & 2903 & 5.6 & 2893 \\
\hline $\begin{array}{l}\text { Machinery and } \\
\text { mechanical } \\
\text { appliances }\end{array}$ & 3,9 & 981 & 2,5 & 1034 & 2,1 & 1159 & 1,6 & 1259 & 1,5 & 1350 \\
\hline $\begin{array}{l}\text { Electrical } \\
\text { equipment }\end{array}$ & 1,4 & 474 & 1,8 & 578 & 1,4 & 616 & 0,9 & 698 & 1,2 & 776 \\
\hline Vehicles & 1,2 & 325 & 1,8 & 569 & 1,2 & 722 & 1,5 & 833 & 1,5 & 707 \\
\hline $\begin{array}{l}\text { Mixed capital, of } \\
\text { which: }\end{array}$ & 34.8 & 905 & 32.3 & 862 & 39.9 & 1004 & 33.3 & 1024 & 28.5 & 1005 \\
\hline $\begin{array}{l}\text { Machinery and } \\
\text { mechanical } \\
\text { appliances }\end{array}$ & 7.6 & 528 & 3.9 & 454 & 5.6 & 561 & 6.7 & 531 & 6.2 & 519 \\
\hline $\begin{array}{l}\text { Electrical } \\
\text { equipment }\end{array}$ & 5.6 & 276 & 4.6 & 268 & 9.3 & 312 & 6.5 & 325 & 6.2 & 327 \\
\hline Vehicles & 9.7 & 149 & 17.2 & 162 & 18.5 & 193 & 16.8 & 195 & 13.7 & 190 \\
\hline $\begin{array}{l}\text { Foreign capital, of } \\
\text { which: }\end{array}$ & 43.4 & 1561 & 54.8 & 1863 & 51.1 & 1968 & 56.8 & 2010 & 62.4 & 2093 \\
\hline $\begin{array}{l}\text { Machinery and } \\
\text { mechanical } \\
\text { appliances }\end{array}$ & 8.3 & 976 & 14.1 & 1107 & 14.4 & 1100 & 15.0 & 1107 & 14.3 & 1193 \\
\hline $\begin{array}{l}\text { Electrical } \\
\text { equipment }\end{array}$ & 21.0 & 563 & 22.3 & 650 & 18.2 & 708 & 21.4 & 717 & 25.9 & 756 \\
\hline Vehicles & 11.8 & 278 & 15.4 & 388 & 13.4 & 444 & 16.5 & 487 & 18.6 & 489 \\
\hline
\end{tabular}

Data source: Authors' calculations based on NIS data

The main goods exported from the medium-high technology sectors are electrical equipment, road vehicles and machinery. Companies with Romanian capital, although the most numerous, achieve the lowest level of export in this category. On national market, these firms are satellites of foreign firms, acting as suppliers of small components and spare parts, while relations with foreign markets are limited by the reduced production capacity and the impossibility to achieve the qualitative criteria.

Table 5.

Geographical orientation of exports from medium-high technology sectors, by type of capital (\% of total exports of medium-high technology goods) and the number of companies

\begin{tabular}{|l|c|c|c|c|c|c|c|c|c|c|c|}
\hline & \multicolumn{3}{|c|}{2008} & \multicolumn{3}{c|}{2010} & \multicolumn{2}{c|}{2012} & \multicolumn{2}{|c|}{2014} & \multicolumn{2}{c|}{2016} \\
\hline & $\begin{array}{c}\text { \% in } \\
\text { value }\end{array}$ & $\begin{array}{l}\text { No. of } \\
\text { comp. }\end{array}$ & $\begin{array}{c}\text { \% in } \\
\text { value }\end{array}$ & $\begin{array}{c}\text { No. of } \\
\text { comp. }\end{array}$ & $\begin{array}{c}\text { \% in } \\
\text { value }\end{array}$ & $\begin{array}{c}\text { No. of } \\
\text { comp. }\end{array}$ & $\begin{array}{c}\text { \% in } \\
\text { value }\end{array}$ & $\begin{array}{c}\text { No. of } \\
\text { comp. }\end{array}$ & $\begin{array}{c}\text { \% in } \\
\text { value }\end{array}$ & $\begin{array}{l}\text { No. of } \\
\text { comp. }\end{array}$ \\
\hline $\begin{array}{l}\text { Export of } \\
\text { medium-high } \\
\text { technology } \\
\text { goods, of which: }\end{array}$ & 100,0 & 4504 & 100,0 & 5120 & 100,0 & 5636 & 100,0 & 6054 & 100,0 & 6072 \\
\hline
\end{tabular}




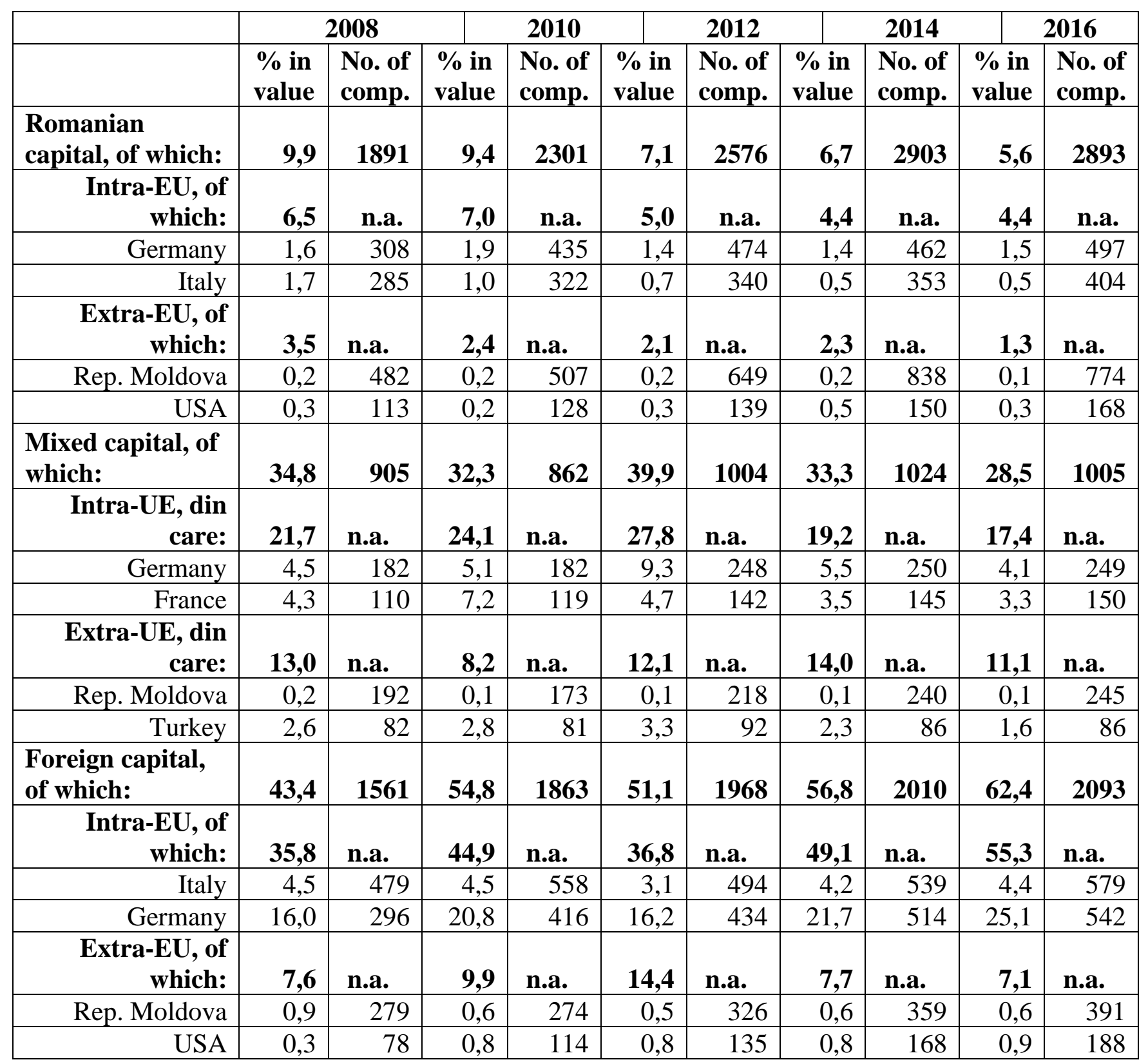

Data source: Authors' calculations based on NIS data

The export markets for goods produced in Romania, irrespective of the type of capital, are determined either by their proximity to the territory of Romania (Republic of Moldova, Turkey, Bulgaria) or by the country of origin of the FDI firms (Italy, France, USA). Also, in the case of export of medium-high technology goods, economic relations with EU countries are the most important ones, while third countries represent a small share of Romanian exports.

The access on the foreign markets of Romanian companies depends on the quality and goods assortment and by the intrinsic aspects of the companies, such as reduced managerial skills, limited financial resources and qualification of the employees. Another important factor is the reduced capacity of the public sector to implement measures to encourage the export activity of small companies and, in particular, to promote Romanian products across the border. 


\section{Exports of medium-low technological products}

In medium and low technology manufacturing sectors, most of the companies concentrate their export activity on plastics, rubber and iron, steel and steel products. In these domains more than $80 \%$ the number of companies exporting medium-low and low-tech products are registered, regardless of the type of their capital. Romanian companies do not record important export performance, their contribution being very low (below 10\% in 2016, although their number is comparable with the number of foreign-owned companies).

Table 6.

Exports of medium-low technology goods of Romania, by type of capital (\% in the total export of medium-high technology goods) and the number of firms in this category

\begin{tabular}{|c|c|c|c|c|c|c|c|c|c|c|}
\hline & \multicolumn{2}{|c|}{2008} & \multicolumn{2}{|c|}{2010} & \multicolumn{2}{|c|}{2012} & \multicolumn{2}{|c|}{2014} & \multicolumn{2}{|c|}{2016} \\
\hline & $\begin{array}{c}\% \text { in } \\
\text { value }\end{array}$ & $\begin{array}{l}\text { No. of } \\
\text { comp. }\end{array}$ & $\begin{array}{c}\% \text { in } \\
\text { value }\end{array}$ & $\begin{array}{l}\text { No. of } \\
\text { comp. }\end{array}$ & $\begin{array}{c}\% \text { in } \\
\text { value }\end{array}$ & $\begin{array}{l}\text { No. of } \\
\text { comp. }\end{array}$ & $\begin{array}{c}\% \text { in } \\
\text { value }\end{array}$ & $\begin{array}{l}\text { No. of } \\
\text { comp. }\end{array}$ & $\begin{array}{c}\% \text { in } \\
\text { value }\end{array}$ & $\begin{array}{l}\text { No. of } \\
\text { comp. }\end{array}$ \\
\hline $\begin{array}{l}\text { Export of } \\
\text { medium-low } \\
\text { technology } \\
\text { goods, of } \\
\text { which: }\end{array}$ & 100.0 & 4018 & 100.0 & 4131 & 100.0 & 4632 & 100.0 & 4861 & 100.0 & 4956 \\
\hline $\begin{array}{l}\text { Romanian } \\
\text { capital, of } \\
\text { which: }\end{array}$ & 9.1 & 1662 & 13.2 & 1718 & 11.4 & 1953 & 9.8 & 2113 & 9.7 & 2230 \\
\hline $\begin{array}{l}\text { Products of } \\
\text { plastic }\end{array}$ & 0.3 & 594 & 0.6 & 692 & 0.7 & 760 & 1.2 & 896 & 1.7 & 976 \\
\hline $\begin{array}{l}\text { Products of pig- } \\
\text { iron, iron and } \\
\text { steel }\end{array}$ & 2.1 & 629 & 2.0 & 613 & 1.9 & 721 & 2.1 & 832 & 2.4 & 846 \\
\hline $\begin{array}{l}\text { Products of } \\
\text { rubber }\end{array}$ & 0.3 & 194 & 0.4 & 215 & 0.6 & 241 & 0.4 & 304 & 0.4 & 333 \\
\hline $\begin{array}{l}\text { Mixed capital, } \\
\text { of which: }\end{array}$ & 63.0 & 841 & 48.2 & 733 & 42.4 & 907 & 42.8 & 906 & 35.9 & 876 \\
\hline $\begin{array}{l}\text { Products of } \\
\text { plastic }\end{array}$ & 0.8 & 418 & 1.2 & 355 & 1.4 & 482 & 1.6 & 490 & 1.7 & 486 \\
\hline $\begin{array}{l}\text { Products of pig- } \\
\text { iron, iron and } \\
\text { steel }\end{array}$ & 5.3 & 334 & 4.7 & 308 & 5.4 & 361 & 4.7 & 348 & 4.0 & 359 \\
\hline $\begin{array}{l}\text { Products of } \\
\text { metal }\end{array}$ & 0.3 & 166 & 0.5 & 136 & 0.5 & 183 & 0.7 & 191 & 0.9 & 205 \\
\hline $\begin{array}{l}\text { Foreign } \\
\text { capital, of } \\
\text { which: }\end{array}$ & 21.9 & 1410 & 36.1 & 1630 & 44.5 & 1761 & 44.6 & 1828 & 51.4 & 1844 \\
\hline $\begin{array}{l}\text { Products of } \\
\text { plastic }\end{array}$ & 1.7 & 771 & 2.4 & 904 & 2.7 & 975 & 3.4 & 1035 & 4.5 & 1069 \\
\hline $\begin{array}{l}\text { Products of pig- } \\
\text { iron, iron and } \\
\text { steel }\end{array}$ & 3.9 & 619 & 6.3 & 714 & 6.6 & 801 & 7.3 & 834 & 7.9 & 869 \\
\hline $\begin{array}{l}\text { Products of } \\
\text { rubber }\end{array}$ & 9.0 & 249 & 13.6 & 316 & 15.3 & 383 & 16.3 & 434 & 18.3 & 447 \\
\hline
\end{tabular}

Data source: Authors' calculations based on NIS data

\section{Exports of low-tech products}

The technological category of goods where Romanian companies hold a larger share, both in terms of number of firms and volume of exported goods, is the low technology sectors. The main goods exported belonging to this category are: wood, wood products and paper. These three types 
of products account for over $40 \%$ of the export value of low technology goods, with a Romanian capital contribution of $10 \%$.

Table 7.

Exports of low-tech goods, by type of capital (\% of the total exports of low-tech goods) and the number of companies in this sector

\begin{tabular}{|c|c|c|c|c|c|c|c|c|c|c|}
\hline & \multicolumn{2}{|c|}{2008} & \multicolumn{2}{|c|}{2010} & \multicolumn{2}{|c|}{2012} & \multicolumn{2}{|c|}{2014} & \multicolumn{2}{|c|}{2016} \\
\hline & $\begin{array}{l}\% \text { in } \\
\text { value }\end{array}$ & $\begin{array}{l}\text { No. of } \\
\text { comp. }\end{array}$ & $\begin{array}{l}\% \text { in } \\
\text { value }\end{array}$ & $\begin{array}{l}\text { No. of } \\
\text { comp. }\end{array}$ & $\begin{array}{l}\% \text { in } \\
\text { value }\end{array}$ & $\begin{array}{l}\text { No. of } \\
\text { comp. }\end{array}$ & $\begin{array}{l}\% \text { in } \\
\text { value }\end{array}$ & $\begin{array}{l}\text { No. of } \\
\text { comp. }\end{array}$ & $\begin{array}{l}\% \text { in } \\
\text { value }\end{array}$ & $\begin{array}{l}\text { No. of } \\
\text { comp. }\end{array}$ \\
\hline $\begin{array}{l}\text { Export of low- } \\
\text { tech goods, of } \\
\text { which: }\end{array}$ & 100.0 & 5143 & 100.0 & 5284 & 100.0 & 5680 & 100.0 & 5709 & 100.0 & 5389 \\
\hline $\begin{array}{l}\text { Romanian } \\
\text { capital, of which: }\end{array}$ & 22.7 & 2280 & 22.6 & 2462 & 21.7 & 2712 & 21.0 & 2822 & 19.1 & 2588 \\
\hline Wood & 2.7 & 622 & 2.9 & 672 & 3.1 & 783 & 3.0 & 798 & 3.5 & 753 \\
\hline Wood products & 4.5 & 424 & 4.2 & 441 & 4.2 & 430 & 4.3 & 459 & 6.3 & 488 \\
\hline Paper & 0.5 & 315 & 0.4 & 333 & 0.3 & 341 & 0.5 & 390 & 1.0 & 448 \\
\hline $\begin{array}{l}\text { Mixed capital, of } \\
\text { which: }\end{array}$ & 21.8 & 1022 & 16.9 & 855 & 23.1 & 1083 & 21.0 & 998 & 17.4 & 936 \\
\hline Paper & 0.6 & 274 & 0.8 & 224 & 0.7 & 327 & 0.7 & 284 & 0.9 & 292 \\
\hline Wood & 2.7 & 285 & 1.9 & 235 & 4.4 & 282 & 2.5 & 271 & 2.7 & 251 \\
\hline Wood products & 2.4 & 207 & 2.6 & 153 & 2.6 & 168 & 3.3 & 158 & 3.6 & 188 \\
\hline $\begin{array}{l}\text { Foreign capital, } \\
\text { of which: }\end{array}$ & 46.6 & 1676 & 56.6 & 1873 & 51.8 & 1870 & 54.0 & 1874 & $\mathbf{5 9 . 0}$ & 1852 \\
\hline Paper & 0.3 & 568 & 0.7 & 595 & 0.9 & 591 & 0.9 & 605 & 1.2 & 682 \\
\hline Wood & 5.3 & 449 & 8.4 & 489 & 6.8 & 521 & 8.7 & 530 & 9.8 & 546 \\
\hline Wood products & 6.9 & 328 & 6.1 & 330 & 6.9 & 362 & 8.0 & 321 & 12.1 & 382 \\
\hline
\end{tabular}

Data source: Authors' calculations based on NIS data

Romanian companies represent the premises of the foreign companies' activity in Romania. Romanian companies act as satellites on the processing market for large foreign. At the same time, there is a strong awareness among both consumers and companies on the existing of natural resources limits. This has led to the emergence of new markets, which are based on renewable resources or creative industries.

The export pattern knows different forms, being in a continuous shift determined first and foremost by new technologies, with impact on the entire economic and social life. Companies that are able to develop or keep up with such technologies, through direct implementation and use, have a better chance to reach the goals of each company: economic expansion (business power by business size), maximizing profits (additional possibilities for innovation / implementation of technologies) and cost reduction (efficiency). Knowledge is the asset of successful companies on any market, therefore human capital represent their most important resource. However, the competition on foreign market is difficult to manage by small firms and hence the volatility of their presence on the respective markets is high.

\section{Conclusions}

Romanian economy is highly dependent on the evolution of the main trading partners, especially from the EU market. The foreign capital companies are the main exporters of goods produced in Romania while the higher share in export is held by medium and low-tech products. The foreign firms are very well developed in the Romanian economic life, producing national 
benefits and taking full advantage of the poor initiative and / or continuity of Romanian entrepreneurship.

The Romanian capital companies with export activity registered lower performance than the mixt or foreign ones and are more volatile on external markets. Their efforts have to concentrate on sustainable and efficient economic development, by increasing the level of processing of the national basic resources, is one of the solutions to balance the trade activity.

Romanian capital is poorly represented in the export of high-tech and medium-high technology goods but have the largest share in the export of low-tech and primary products, such as wood processing and agricultural goods. Against this background, agriculture is a domain that should be supported in terms of upgrading to the highest possible level from technological point of view, to increase production and its efficiency, while supporting the food processing industry in order to increase the added value on export. Associating small agricultural producers might be a cost-effective solution. The primary products must not be exported as such, but processed to the closest level to the finished product for which there is a demand on foreign markets. Moreover, if this can be done through companies with Romanian capital, the export can provide sustainable long-term economic growth, with direct effects on the living standards of the population.

Not only agriculture has important export potential, but also other areas based on natural resources, such as wood processing. High-quality furniture production can benefit to a large extent. This would lead to regional development through job creation, increased local culture and education. The export competitiveness might be improved through:

- concentration of domestic capital in medium and large firms capable of consistent investment in technology;

- increasing labor productivity;

- expanding export markets in geographic areas with potential - extra-EU.

Supporting the export activity of Romanian companies by the state through specific instruments represents a solution for the development of the export production and the expansion on other markets. Possible mechanisms would be - facilitating access to technology transfer funding, staff training for the exploitation of new technologies, subsidizing specific Romanian products, etc.

\section{Bibliography}

1. Aitken, B. \& Harrison, A., 1999. Do Domestic Firms Benefit from Direct Foreign investments? Evidence from Venezuela. The American Economic Review, 89(3), pp. 605-618.

2. Bănică, E. \& Vasile, V., 2017. Romanian Foreign Trade after Brexit - Impact, Main Challenges and Limits. Romanian Journal of Economics, 45/2017(ONLINE ISSN 23444657), pp. 63-86.

3. Bănică, E. \& Vasile, V., 2018. Exports, industries' technological intensity, capital and labour market in Romania. Romanian Journal of Economics, ONLINE ISSN 2344-4657(46/2018), pp. 76-95.

4. Bănică, E. \& Vasile, V., 2018. The Export Efficiency Dynamics of Romanian Owned Capital Companies. Limits and Challenges in a Globalised World. The Annals of the University of Oradea, Economic Science, 1st issue/July 2018(Tom XXVII-2018), pp. 25-38.

5. Blinder, A., 2009. How many US jobs might be offshorable?. World Economics, Volume 2(10), p. 41-78.

6. Cerchez, O., 2007. Eficienţa economică a comerţului exterior. s.1.:Logos.

7. EC, 2018. Country Report Romania 2018. [Online] Available at: https://ec.europa.eu/info/sites/info/files/2018-european-semester-country-reportromania-en.pdf

[Accessed 28 March 2018].

8. European Investment Bank, 2018. Investment Report 2017/2018 from recovery to sustainable growth. [Online] 
Available at: http://www.eib.org/attachments/efs/economic_investment_report_2017_en.pdf [Accessed 03 2018].

9. Fernandez, A., Freund, C. \& Pierola, M. D., 2016. Exporter behaviour, country size and stage of development: Evidence from the exporter dynamics database. Journal of Development Economics, 119(http://dx.doi.org/10.1016/j.jdeveco.2015.10.007), pp. 121-137.

10. Ghibuțiu, A., 2006. Sistemul Comercial Multilateral și Globalizarea. vol.205 ed. s.l.:Academia Română, Institutul Național de Cercetări Economice, Seria Probleme Economice .

11. Görg, H. \& Greenaway, D., 2003. Much Ado About Nothing? Do Domestic Firms Really Benefit from Foreign Direct Investment?. Institute for the Study of Labor, p. Discussion Paper No. 944.

12. Gorg, H. \& Strobl, E., 2001. Multinational Companies and Productivity Spillovers: A Meta Analysis. The Economic Journal, Volume 111, pp. 723-39.

13. Kokko, A., Tansini, R. \& Zejan, M., 2001. Trade Regimes and Spillover effects of FDI: Evidence from Uruguay. Weltwirtschaftliches Archiv / Review of World Economics, Issue 137.

14. Liedtke, P. M., 2000. Global Economics - Overcoming Tomorow's Challenges. Progress Newsletter, Geneva, Issue 31.

15. NSI Romania, 2017. International Trade Yearbook of Romania. 2017 ed. Bucharest: NSI Romania.

16. Peluffo, A., 2015. Foreign Direct Investment, Productivity, Demand for Skilled Labour and Wage Inequality: An Analysis of Uruguay,. The World Economy, Institute of Economics, School of Economics, University of the Republic, Uruguay.

17. Vasile, V., 2007. Effects Of Integration And Globalisation On Labour Market, s.1.: http://www.asociatiaeconomistilor.ro/documente/simpozion_AGER_2007_engleza.pdf.

18. Vasile, V. \& Banica, E., 2016. Sustainable economic growth through expernal trade. The Annals of the University of Oradea, Volume Economic Sciences tom XXV, 2nd issue / December 2016, pp. 132-145, ISSN 1222-569X, ISSN 1582-5450.

19. Vasile, V. \& Zaman, G., 2005. Dezvoltarea durabilă. București: Editura Expert.

20. Vasile, V. \& Zaman, G., 2012. Macroeconomic Impact of FDI in Romania. Procedia Economics and Finance, pp. vol. 3, 3-11, 11 https://ac.els-cdn.com/S221256711200113X/1s2.0-S221256711200113X-main.pdf?_tid=ad932f4c-d75a-11e7-b02200000aab0f01\&acdnat $=1512217192 \_7 \mathrm{a} 727 \mathrm{~b} 467 \mathrm{c} 5 \mathrm{eafab} 4 \mathrm{e} 79 \mathrm{cb} 2 \mathrm{ca} 29216 \mathrm{c} 9$.

21. WEF, 2017. World Economic Forum, The Global Competitiveness Report, http://www3.weforum.org/docs/GCR2017-

2018/05FullReport/TheGlobalCompetitivenessReport2017\%E2\%80\%932018.pdf: World Economic Forum.

22. World Bank Group, 2018. Doing Business 2018, Reforming to Create Jobs. [Online] Available at:

http://www.doingbusiness.org/ /media/WBG/DoingBusiness/Documents/AnnualReports/English/DB2018-Full-Report.pdf [Accessed 03 2018].

23. Zaman, G. \& Vasile, V., 2006. Transferul Tehnologic şi Investiţiile - Priorităţi Ale Dezvoltării Durabile. București: Academia Română, Institutul Naţional de Cercetări Economice, Institutul de Economie Naţională, Editura Expert. 